\title{
Phytoplankton community structure and water quality of Red River, Vietnam
}

\author{
Cấu trúc quần xã thực vật nổi và chất lượng nước sông Hồng, Việt Nam \\ Research article
}

Duong, Thi Thuy ${ }^{1}$; Le, Thi Phuong Quynh ${ }^{2}$; Ho, Tu Cuong ${ }^{1}$; Vu, Thi Nguyet ${ }^{1}$; Hoang, Thi Thu Hang ${ }^{1}$; Dang, Dinh Kim ${ }^{1}$; Lu, Xixi ${ }^{3}$

${ }^{1}$ Institute of Environmental Technology, Vietnam Academy of Science and Technology, 18 Hoang Quoc Viet Road, Cau Giay, Hanoi, Vietnam; ${ }^{2}$ Institute of Natural Product Chemistry, Vietnam Academy of Science and Technology, 18 Hoang Quoc Viet Road, Cau Giay, Hanoi, Vietnam; ${ }^{3}$ Department of Geography, National University of Singapore, Arts Link 1, Singapore 117570, Singapore

\begin{abstract}
This study aimed to describe the distribution and relative abundance of the phytoplankton obtained during the two seasons (rainy and dry seasons) from the Red river system. The water and phytoplankton samples were monthly collected during the year 2012 at four sampling stations along the Red River (Yen Bai, Vu Quang Hoa Binh,and Ha Noi) . Environmental variables (e.g. temperature, dissolved oxygen, $\mathrm{pH}$, suspended solids, conductivity, TDS, $\mathrm{NO}_{3}-\mathrm{N}, \mathrm{NH}_{4}-\mathrm{N}, \mathrm{PO}_{4}-\mathrm{P}$, Total Phosphorus; and DOC) and phytoplankton (e.g. cell density and relative abundant species) were analyzed. Six phytoplankton classes were identified with the Bacillariophyceae dominating in the phytoplankton community. A distinct seasonal variation in phytoplankton structure was observed with high cells density in dry season and low values in rainy season. PCA (Principal Component Analysis) showed that suspended solid factor that governed the temporal and spatial distribution of phytoplankton structure in the Red River system.
\end{abstract}

Nghiên cưu này trình bày sư phân bố và độ phong phú tuoong đối của quần xã thực vật nổi vào mùa mua và mùa khô trong hẹ thống sông Hồng. Các mẫu nước và thực vật nổi được thu hàng tháng trong năm 2012 tại 4 điểm trên sông Hồng (Yên Bái, Vu Quang, Hòa Bình và Hà Nội). Các thông số môi truờng (nhiệt độ, luợng oxy hòa tan, $p H$, chất rắn lo lửng, độ dẫn, TDS, NO3-N, NH4-N, PO4-P, T-P và DOC) và thưc vật phù du (mật độ tế bào, độ phong phú tuơng đối) đã được phân tích. Sáu lớph tảo được được xác định với tảo silíc chiếm uu thế trong quần xã thực vật phù du. Sinh khối thực vật đạt giá trị cao vào mùa khô trong khi thấp vào mùa mura. Phân tích hợp phần chính cho thấy yếu tố chất rắn lo lửng đóng vai trò quan trọng việc xác định biến động thời gian và không gian cấu trúc quần xã thực vật nổi trong hệ thống sông Hồng.

Keywords: phytoplankton structure, environmental factors, water quality, Red river system

\section{Introduction}

Phytoplankton are free-floating microscopic plants, account for $1 \%$ of the photosynthetic biomass on Earth, but responsive for $50 \%$ of global primary production and they are fundamental in trophic energy transfer for aquatic ecosystems (Field et al., 1998). Phytoplankton assemblage contributes a major group of primary producers in aquatic ecosystem and plays a vital role in the trophic dynamics and aquatic ecosystem process. Phytoplankton community are known for water quality assessment and also use as indicators of climatic changes and human impacts. The temporal and spatial distribution of phytoplankton assemblage is affected by many biotic and abiotic factors, such as $\mathrm{pH}$, light, temperature, nutrients, grazing, competition, parasitism etc. Phytoplankton community are sensitive to environmental changes. Changes in the phytoplankton community structure and biomass greatly affect the aquatic ecosystem functions, including shifts in nutrient cycles, food web, and fisheries (Paerl and Peierls 2008).

The Red River (Vietnam and China), which covers a watershed area of $156450 \mathrm{~km} 2$, is a good example of a South-East Asian river system, strongly affected by 
climate and human activities. In the upstream Red River basin, deforestation and land use changes are considered to cause a variety of environmental impacts such as increased flooding and dramatically increased soil erosion. In its downstream sector, the intensive farming practices with increasing use of nitrogen and phosphorus fertilizers, the increase of population, the economic industrial development and urbanization have strongly affected the water quality of the Red River system and also influenced the coastal zone ecosystem (Le et al., 2007; 2010). In particular the nitrogen and phosphorus export from the watershed resulted not only in nutrient contamination of river water, but also in a risk for eutrophication, both in downstream, stagnant, sectors of the drainage network, particularly in the delta area, and in the coastal areas. On the other hand, reservoir construction results in decreasing concentration of silica (Si) and suspended solids (SS) associated nutrients (Luu et al 2012). The decreasing Si loading, together with increasing nitrogen and phosphorus contamination, often result in the occurrence of non-diatoms harmful algal bloom.

Till now, there are lacks of the thorough studies about the total effect of all the physico-chemical and biological parameters on the water quality from the upstream to the downstream of the Red River catchment. In addition, the application of bioindicators in the monitoring of the water quality has not yet been taken into account. The biodiversity and structural variations of micro-algal community relating to the change of environmental parameters have been rarely studied to apply for monitoring the water quality of the Red River catchment. Investigation in the relationship between the environmental factors and ecological structure of algal community not only exposes the effect of the environmental changes on the ecology but also suggests measures to control and reduce the pollutants in the aqueous bodies. The main objectives of the present study are to describe the structure, distribution of phytoplankton community and to characterize the main environmental factors that relate to the pattern of phytoplankton in the Red river.

\section{Materials and Methods}

\subsection{Study area, sampling and analysis}

\subsubsection{Study area}

The sampling area is located in the Red River delta (North Vietnam). The monthly sampling campaigns were conducted during the period from January to December 2012. The water and phytoplankton samples were collected at four gauging stations (Fig 1): Hoa Binh, outlet of the Da river (Hoa Binh province); Vu Quang, outlet of the Lo river (Phu Tho province); Yen Bai, outlet of the Thao river (Yen Bai province); and at Hanoi, on the main axis of the Red River.

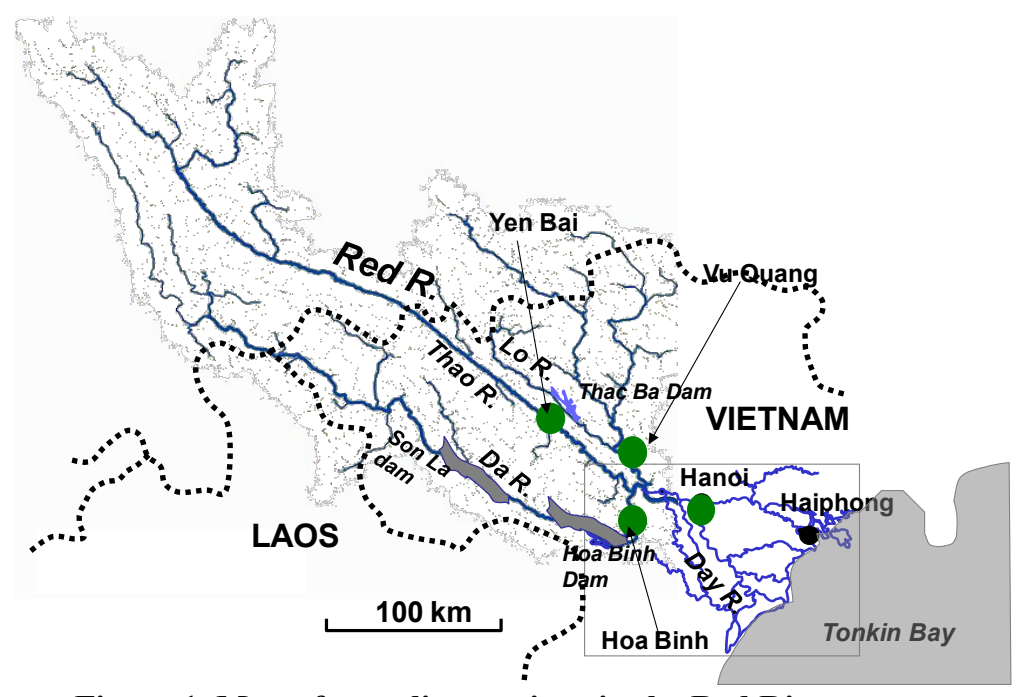

Figure 1. Map of sampling stations in the Red River system

\subsubsection{Sampling}

Water samples were monthly collected from surface layer $(0-35 \mathrm{~cm})$ from January to December 2012 at 4 sites (HB, VQ, YB and HN) in the reservoir as shown in the Figure 1. For the present study, average values of six sampling stations are presented. Physical factors (temperature, $\mathrm{pH}$, dissolved oxygen (DO) and conductivity) were measured in situ using a multi-parameter probe (Model WQC-22 A, TOA). Water samples for nutrients determinations $\left(\mathrm{PO}_{4}{ }^{3-}-\right.$ $\left.\mathrm{P}, \mathrm{NH}_{4}^{-}-\mathrm{N}, \mathrm{NO}_{3}^{-}-\mathrm{N}, \mathrm{NO}_{2}^{-} \mathrm{N}\right)$ were collected near the surface, filtered through Whatman GF/C filters $(0.45 \mu \mathrm{m})$ and kept in polypropylene sampling at $4{ }^{\circ} \mathrm{C}$ in darkness analyzed as soon as possible. Phytoplankton samples were collected using plankton net ( $40 \mu \mathrm{m}$ mesh size) and immediately fixed with formaldehyde solution at a $5 \%$ $(v / v)$ final concentration for species identification

\subsubsection{Analysis}

All analyses were conducted according to American Public Health Association (APHA 1998). Water samples for chlorophyll a determination were filtered through $\mathrm{GF} / \mathrm{C}$ membrane filters extracted in acetone and measured spec- 
trophotometrically (Lorenzen 1967). Phytoplankton samples were collected by using plankton net $(40 \mu \mathrm{m}$ mesh size) and immediately fixed with formaldehyde solution at a $5 \%(\mathrm{v} / \mathrm{v})$ final concentration for species identification. Phytoplankton species were identified according to its morphology using light microscopic observation (Olympus BX51). The following taxonomic literature was used for the identification of cyanobacteria: Duong (1996); Komárek and Anagnostidis (1989; 1999; 2005). Krammer and Lange-Bertalot (1986-1991) was used for diatom identification. Das Phytoplankton des SüßwassersDie Binnengewässer" (Huber-Pestalozzi (1955, 1961, 1968, 1982, 1983), Den Hoek et al (1995), Duong and Vo (1997) were used for other algae identification. For phytoplankton enumeration, one litre of water was preserved with $10 \mathrm{ml}$ Lugol's iodine solution and then was sedimented for $48 \mathrm{~h}$ prior to counting. Number of cells was counted by using a Sedgewick-Rafter cell method (Karlson et al. 2010).

\subsection{Data analysis}

A Principal Component Analysis (PCA) using SPAD Software (version 5.6, Decisia, Paris, France) was performed to elucidate the relationships between the phytoplankton and environmental factors.

\section{Results and discussion}

\subsection{Red River water quality}

The results of physical and chemical characteristics during the study period from Jannuary to December 2012 in the Red river are summarized in Table 1.4 sampling sites presented an average temperature of $24^{\circ} \mathrm{C}$ and $\mathrm{pH}$ values do not show significant differences, although they presented values slightly inferior to neutral $\mathrm{pH}$ (7.5-7.7). The lowest and highest levels of average dissolved oxygen were recorded at Hanoi (3.9-7.2mg/L), respectively. At 2 stations Yen Bai and $\mathrm{Vu}$ Quang, the dissolved oxygen concentration was ranged from 3.8-6.1 mg/L and 3.9-55 $\mathrm{mg} / \mathrm{L}$, respectively. During the sampling period, turbidity differed significantly $(\mathrm{p}<0.05)$ between sites and ranged from 11 NTU (at Hoa Binh) to 67 NTU (at Yen Bai). Turbidity in Hoa Binh site was lowest compared to the others due to the operation of the Hoa Binh and Son La reservoir of Da River. Since the impoundment of the second big dam, Son La, in the Da river, turbidity in this period were much lower than before (e.g. Le et al., 2007). Turbidity decline in the Hoa Binh site can be mainly explained by the low sediment load at the Da and Lo River resulting from two main dam reservoirs (HoaBinh and ThacBa), which have blocked the sediment transport through trapping within the reservoirs.

Table 1. Environmental parameters of the Red River system at four studied stations: combined observations from January to December 2012 (average values and min-max values). Sites: YB (Yen Bai); HB (Hoa Binh); VQ (Vu Quang) and HN (Ha Noi)

\begin{tabular}{lrrrrrrrrr}
\hline Stations & $\mathbf{p H}$ & $\begin{array}{r}\mathbf{T} \\
\left({ }^{\circ} \mathrm{C}\right)\end{array}$ & $\begin{array}{r}\mathbf{D O} \\
(\mathrm{mg} / \mathrm{l})\end{array}$ & $\begin{array}{r}\text { Turbidity } \\
(\mathrm{NTU})\end{array}$ & $\begin{array}{r}\text { Conductivity } \\
(\mu \mathrm{S} / \mathrm{cm})\end{array}$ & $\begin{array}{r}\mathbf{N O}_{\mathbf{3}} \\
(\mathrm{mgN} / \mathrm{L})\end{array}$ & $\begin{array}{r}\mathbf{N H}_{4} \\
(\mathrm{mgN} / \mathrm{L})\end{array}$ & $\begin{array}{r}\mathbf{P O}_{4} \\
(\mathrm{mgP} / \mathrm{L})\end{array}$ & $\begin{array}{r}\mathbf{T P} \\
(\mathrm{mgP} / \mathrm{L})\end{array}$ \\
\hline Mean & 7.6 & 24.2 & 4.6 & 67 & 163 & 0.67 & 0.159 & 0.044 & 0.19 \\
Min & 6.8 & 14 & 3.7 & 18 & 139 & 0.48 & 0.058 & 0.010 & 0.06 \\
Max & 8.1 & 31 & 6.1 & 168 & 185 & 0.93 & 0.352 & 0.079 & 0.37 \\
\hline Mean & 7.5 & 23.9 & 4.6 & 11 & 165 & 0.42 & 0.118 & 0.041 & 0.11 \\
Min & 6.8 & 15 & 3.5 & 2 & 149 & 0.23 & 0.038 & 0.005 & 0.03 \\
Max & 8.2 & 33 & 5.6 & 44 & 196 & 0.59 & 0.222 & 0.085 & 0.21 \\
\hline Mean & 7.5 & 24.1 & 4.9 & 13 & 187 & 0.70 & 0.137 & 0.040 & 0.13 \\
Min & 6.8 & 14 & 3.9 & 2 & 156 & 0.49 & 0.026 & 0.011 & 0.08 \\
Max & 8.0 & 34 & 5.6 & 55 & 217 & 0.86 & 0.270 & 0.087 & 0.21 \\
\hline Mean & 7.7 & 23.9 & 4.3 & 35 & 174 & 0.59 & 0.131 & 0.052 & 0.16 \\
Min & 6.7 & 16 & 3.0 & 12 & 93 & 0.26 & 0.026 & 0.004 & 0.04 \\
Max & 8.4 & 33 & 7.2 & 171 & 199 & 0.86 & 0.296 & 0.172 & 0.53 \\
\hline
\end{tabular}

The mean conductivity value ranged from 163 to 187 $\mu \mathrm{S} / \mathrm{cm}$. No significant difference in conductivity was observed between the two stations Yen Bai and $\mathrm{Vu}$ Quang. However, marked difference was observed between Vu Quang, Ha Noi sites and Yen Bai, Hoa Binh. In the river basins of Vietnam, nutrients $(\mathrm{N}, \mathrm{P})$ mainly come from fertilizers on the field and from anthropological waste, so the variation of nutrient concentrations in the rivers is complicated. Overall, the high concentration of nutrients comes from the populated centers where the wastewater discharged directly into the river. In rural areas, concentrations of $\mathrm{N}, \mathrm{P}$ are high in the time when farmers are using more chemical fertilizers, especially the runoff occurs when rainy season ( $\mathrm{Vu}$ Huu Hieu et al, 2010). With regard to the trophic conditions of the Red river, inorganic nutrients $(\mathrm{N}$ and $\mathrm{P}$ ) covered a wide range of concentrations. Average concentrations of nitrate, ammonium, phosphate and total phosphate ranged from 
0.4-0.7 mgN/L; 0.13-0,16 mgN/L; $0.04-0.522 \mathrm{mgP} / \mathrm{L}$ and $0.11-0.19 \mathrm{mgP} / \mathrm{L}$, respectively. There were no significant difference in nutrient concentrations between sampling stations and seasons $(p<0.05)$. According to the Organization for Economic Cooperation and Development criteria (OECD, 1982), the water quality of the Red River can be classified as eutrophic.

\subsection{Phytoplankton community}

During our study, phytoplankton community from 4 stations in the Red river system was presented by six classes: Bacillariophyceae, Chlorophyceae, Euglenophyceae, Cryptophyceae, Cyanobacteria and Dinophyceae. The corresponding relative abundances of these groups taxa were 58\% (Bacillariophyceae), 22\% (Chlorophyceae), $17 \% \quad$ (Cyanobacteria) $\quad 13 \% \quad$ (Cryptophyceae), 0,5\% (Euglenophyceae) and $0,4 \%$ (Dinophyceae). The phytoplankton community in the Red river system consists mostly of widely distributed species. The dominant species were similar at study sites. Across the sampling stations, the major taxa of phytoplankton in terms abundance for the class Bacillariophyceae were planktonic diatoms (Aulacoseira (A. granulata), Melosira (M.varians), and Cyclotella (C. sp; C. meneghiniana). Bacillariophyceae were also dominated in the Day, Nhue and ToLich rivers (Duong et al., 2012). The Aulacoseira has been reported as dominant genus in many Brazilian ecosystems, and was considered as a good indicator of turbulence water (Melo-Magalhães et al, 2011). For the class Chlorophyceae, Scenedesmus was identified and predominated at all sampling site during study period. For the class Cyanobacteria, Oscillatoria sp was predominant at all site while Hoa Binh site recorded high abundance of the genus Microcystis.
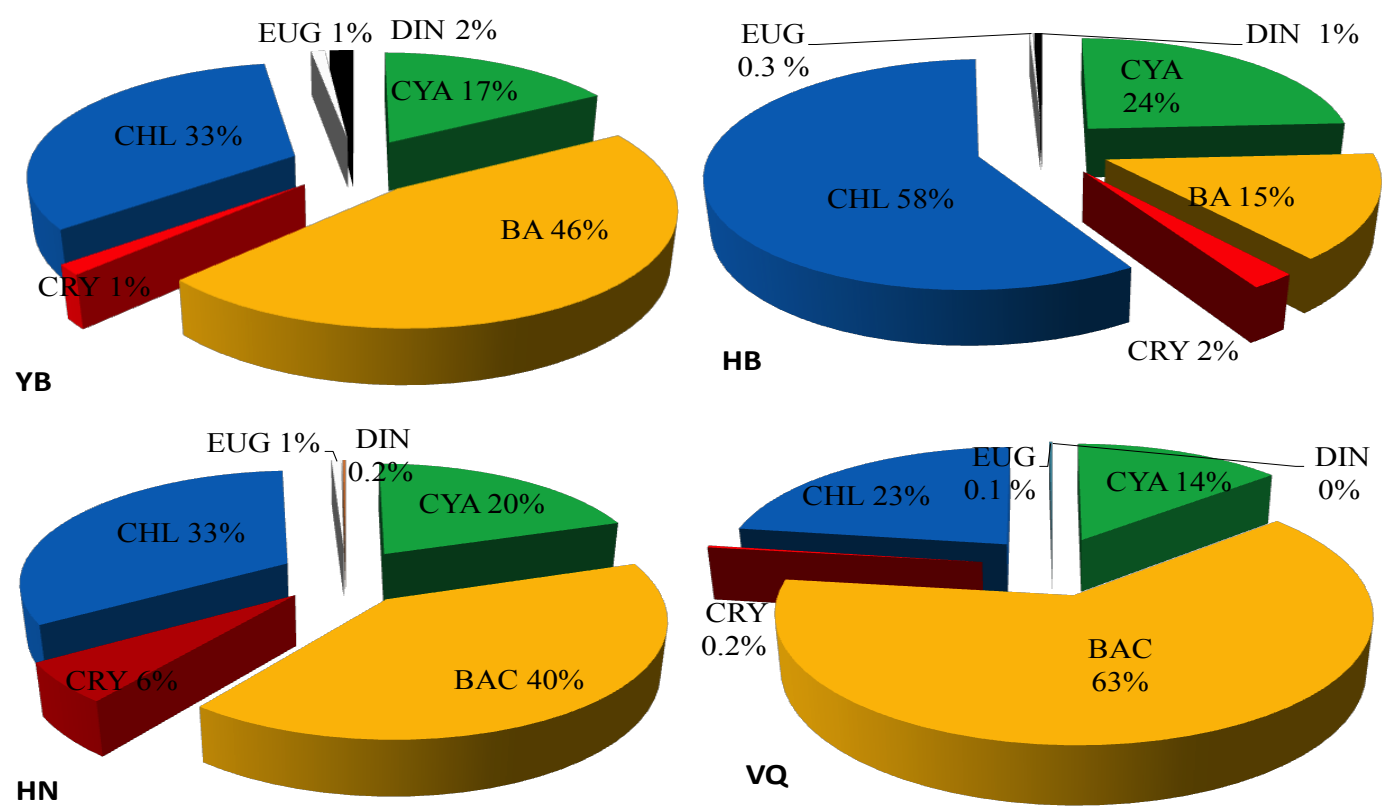

Figure 2. Phytoplankton composition of the Red River system at 4 gauging stations during the year 2012

The main systematic groups of phytoplankton in the Red river system during the year 2012 at 4 samling sites were shown in figure 2 . Generally, the abundance and taxonomic patterns were very similar at the three sites (Yen Bai, $\mathrm{Vu}$ Quang and Ha Noi). Abundance of phytoplankton at the Hoa Binh site was quite different from other sites with dominance of Chlorophyceae in the community and followed by Cyanobacteria and Bacillariophyceae. Biomass of phytoplankton assembalge in the Red rive system during dry and rainny seasons was presented in figure 3 . Phytoplankton density varied seasonally with high values in dry season (Jannuary to March 2012 and November to December, 2012) around 129288 cell $\mathrm{L}^{-1}$ and with low values in rainy season from June to August about 56856 cell. $\left.\mathrm{L}^{-1}\right)$.

Changes of phytoplankton density throughout the investigation related with the abundance of Bacillariophyceae group. In fact, the mean cell density was 2.5 fold higher in dry than in rainy period. Agreeing with what has al- ready been pointed out by Claps (1996), a reduction in algal population during rainy season and floods could be seen. The highest phytoplankton densities observed during the dry season may be due to the increase of solar radiation intensity as well as the reduction in input turbid materials from other tributaries of the Red River (Ewa et al., 2013). Relations between measured environmental variables and phytoplankton assemblages of the Red river sytem were explored using PCA (Principal Component Analysis) (Figure 4). The first two axes account for 50\% of the variance and ordination separated clearly two different phytoplakton community structures. The first axis (accounting for $24.5 \%$ of variance) separates phytoplankton communities in rainy season correlated with environmental variables such as $\mathrm{SS}, \mathrm{pH}, \mathrm{Chl}$ a, Temp, TP, whereas axis 2 accounts for $16 \%$ of the explained variability in which phytoplankton assemblages related to environmental factors such as DO, DOC, $\mathrm{P}_{-} \mathrm{PO}_{4}, \mathrm{~N}-\mathrm{NH}_{4}$, conductivity and $\mathrm{Si}$. The phytoplanktons are primary producers in the food web of aquatic ecosystem. Their distri- 
bution, structure and activities are in a direct relation with the environmental factors.

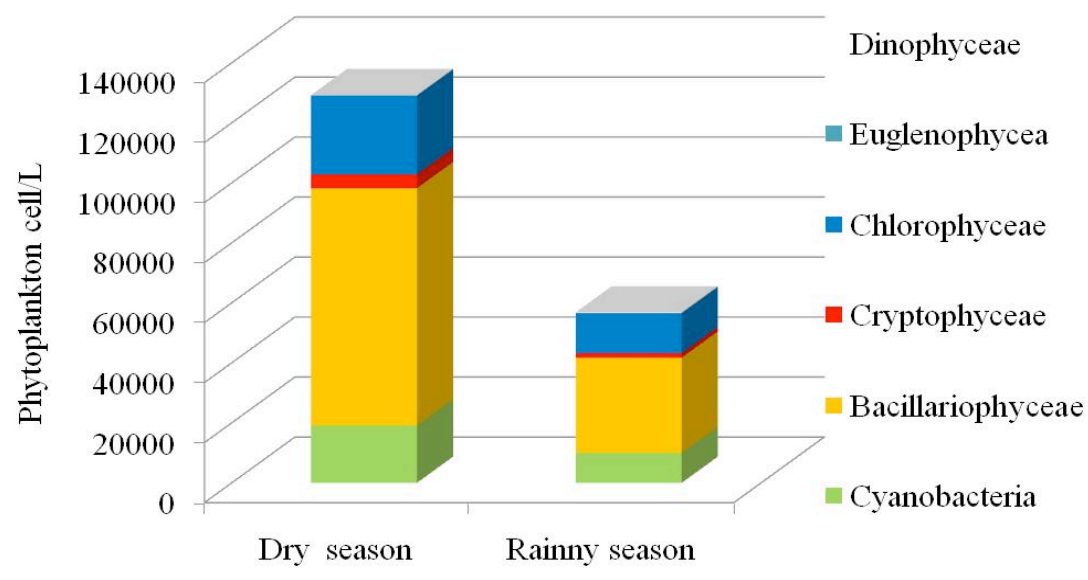

Figure 3. Phytoplankton density in the Red river system during the study period from Jannuary to December 2012

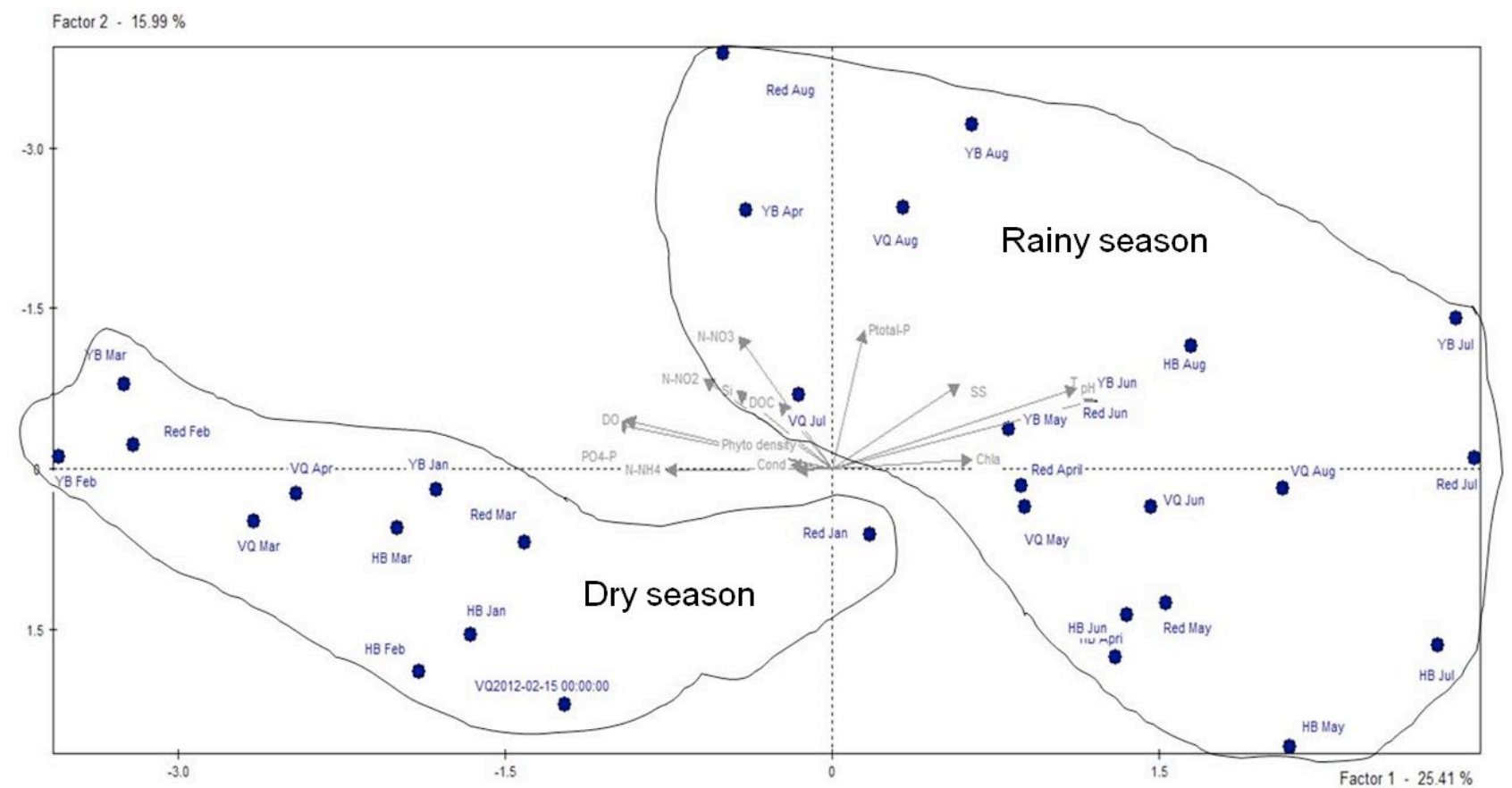

Figure 4. Principal Component Analysis based on environmental parameters and relative abundances of phytoplankton at 4 sampling stations in the Red River from January to December 2012.

Karikal (1995) reported that the occurrence and development of phytoplankton groups in the aquatic body were controlled by a single environmental factor or a group of the factors, which varies in different aquatic bodies. A study in German lowland River underlined that variation in structure of riverine phytoplankton assemblages was briefly affected by hydrological regime (flow velocity) and nutrients (TP and dissolved inorganic nitrogent, DIN) (Wu et al., 2011).

In this study, PCA analysis showed that suspended solid factor that governed the temporal and spatial distribution of phytoplankton structure in the Red River system. This result is consisted with $\mathrm{Wu}$ et al. (2011) and Jiang et al. (2012) that showed the distribution of phytoplankton was influenced by temperature, nutrients, salinity and suspended solid content. The biomass of phytoplankton in the Red river system reached the highest value in the dry season and lowest one in the rainy season. Our results correspond to the observations of Moura et al. (2013). The highest phytoplankton densities observed during the low water level (dry searson) is probably due to the increasing input of nutrients from terrestrial run-off, wastewater thus stimulating phytoplankton growth. Our results correspond to the observations of Moura et al. (2013). High phytoplankton cell density during low discharge and low water flow has been found in eutrophic rivers (Grabowska and Mazur-Marzec, 2011). However, Adon et al. (2011) provided evidence that the phytoplankton density in a tropical reservoir reached maximum val- 
ues in the dry seasons. In our study, diatom was observed to be the dominant group at all monitoring stations of the Red River. Diatom often observed in the fresh and marine water is used as bioindicators for the water quality in the aquatic environment (Duong et al, 2007).

\section{Conclusions}

The results showed that the values of almost the monitoring parameters of the water quality in the Red River system were in the permitting limit of the Vietnamesse standards for the surface water quality (TCVN 5942:1995, column B). Six phytoplankton classes were identified with the Bacillariophyceae dominated in the phytoplankton community.

Phytoplankton density varied seasonally with high values in dry season and values in rainy season. PCA analysis showed that suspended solid factor that governed the temporal and spatial distribution of phytoplankton structure in the Red River system.

\section{Acknowledgements}

This work was conducted within the framework of the projects ARCP2013_06CMY_Quynh and IFS W/4674-2. The authors are grateful to the Asia-Pacific Network for Global Change Research (APN) and the International Foundation for Science (IFS) for their financial support.

\section{References}

[1] Adon M.P., Ouattara A., Gourene G (2011). Seasonal variation in the diversity and abundance of phytoplankton in a small African tropical reservoir. African Journal of Microbiology Research 5(18): 26162626.

[2] Moura A.N., Severiano JS., Tavares NKA., Dantas EW (2013). The role of a cascade of reservoirs and seasonal variation in the phytoplankton structure in a tropical river. Braz J Biol 73(2):291-298.

[3] APHA (1998) American Public Health Association. American Water Works Association (AWWA), Water Environment Federation (WEF). Standard methods for the examination of water and wastewater, 20th edn. American Public Health Association, Washington.

[4] Claps, C. 1996. Structure and dynamics of epipelic algae from a plain river (Samborombon River, Buenos Aires, Argentina), Arch. Hydrobiol., 137: 251263.

[5] Duong DT (1996) Taxonomy of Cyanobacteria of Vietnam. Agriculture Publishing House, Hanoi. $122 \mathrm{pp}$.

[6] Duong, D.T, Vo, H (1997) Fresh algae of Vietnam: taxonomy of chlor-ococcales. Agriculture publishing house, Hanoi, pp 503.

[7] Duong, T.T., Feurtet-Mazel, A., Coste, M., Dang, D. K., Boudou, A (2007). Dynamics of diatom colonization process in some rivers influenced by urban pollution (Hanoi, Vietnam). Ecological Indicators 7: 839-851

[8] Ewa, E.E., Iwara, A.I., Alade, A.O., Adeyemi, J.A (2013). Spatio-temporal Distribution to Phytoplankton in the Industrial Area of Calabar River, Nigeria. Advances in Environmental Biology, 7(3): 466-470.

[9] Field, C.B., Behrenfeld, M.J., Randerson, J.T., Falkowski, P (1998). Primary production of the biosphere: integrating terrestrial and oceanic components. Science 281: 237-242

[10] Grabowska M., Mazur-Marzec, H., 2011. The effect of cyanobacterial blooms in the Siemianówka Dam Reservoir on the phytoplankton structure in the Narew River. Oceanological and Hydrobiological Studies 40:p. 19-26.

[11] Jiang, Z.B., Chen, Q.Z., Zeng, J.N., Liao, Y. B., Shou, L., Liu, J (2012). Phytoplankton community distribution in relation to environmental parameters in three aquaculture systems in a Chinese subtropical eutrophic bay. Mar Ecol Prog Ser 446:73-89

[12] Karlson, B., Cusack, C., Bresnan, E (2010) Microscopic and molecular methods for quantitative phytoplankton. Intergovernmental Oceanographic Commission of UNESCO, p109.

[13] Komárek, J., Anagnostidis, K (1989) Modern approach to the classification system of Cyanophytes 4-Nostocales. Arch fur Hydrobiol Suppl 82: 247345 .

[14] Komárek, J., Anagnostidis, K (1999) Cyanoprokaryota, 1. Teil, Chroococcales. - In: Ettl, H., Gärtner, G., Heynig, H., Mollenhauer, D. (eds): Süsswasserflora von Mitteleuropa 19/1 (pp 1-548). Fischer Ver lag, Jena.

[15] Komárek, J., Anagnostidis, K (2005) Cyanoprokaryota-2. Teil/ 2nd Part: Oscillatoriales. In: Büdel, B., Krienitz, L., Gärtner, G., Schagerl, M. (Eds.), Süßwasserflora von Mitteleuropa 19/2. Elsevier/Spektrum, Heidelberg.

[16] Komárek, J., Anagnostidis, K. 1986. Modern approach to the classification system of cyanophytes. 2- Chroococcales. - Arch. Hydrobiol. Suppl. 73/Algol. Stud. 43: 157-226

[17] Krammer, K., Lange-Betarlot, H (1986 - 1991) Bacillariophyceae. 1.Teil: Naviculaceae. 876 p; 2 . Teil: Bacillariaceae, Epithemiaceae, Surirellaceae, 596 p; 3. Teil: Centrales, Fragilariaceae, Eunotiaceae, 576 p; 4. Teil: Achnanthaceae. Kritische Ergänzungen zu Navicula (Lineolatae) und Gomphonema. 437 p. In: H, Ettl Gerloff, J Heynig, H Mollenhauer, D. (Eds.), Süßwasserflora von Mitteleuropa. Gustav Fischer Verlag, Stuttgart, 2485 pp.

[18] Le, T.P.Q., Billen, G., Garnier, J., Thery, S., Fezard, 
C., Chau, V.M (2005). Nutrient (N, P) budgets for the Red River basin (Vietnam and China). Global Biogeochem Cycles 19(2): 1-16.

[19] Le, T.P.Q., Garnier, J., Billen, G., Thery S., Chau, V.M (2007). The changing flow regime and sediment load of the Red River, Viet Nam. J Hydrology 334, 199-214.

[20] Lorenzen J (1967) Determination of chlorophyll and pheo-pigments: spectrophotometric equations. Limnol Oceanogr 12:343-346.

[21] Luu, T.N.M., Garnier, J., Billen, G., Orange, D., Nemery, J., Le, T.P.Q., Tran, H.T., Le, LA (2010) Hydrological regime and water budget of the Red River Delta (Northern Vietnam). Journal of Asian Earth Sciences 37:219-228.

[22] Melo-Magalhães, E.M., Moura, A.N., Medeiros,
P.R.P., Lima, E.L., Koening, M.L (2011). Phytoplankton of the São Francisco River estuarine region (northeastern Brazil): a study of its diversity. Braz. J. Aquat. Sci. 15(1): 95-105.

[23] Nweze, N. O. 2006. Seasonal variations in phytoplankton in Ogelube lake, a small natural West African lake. Lakes and Reservoirs Research and Management 11: $63-72$.

[24] Paerl, H.W., Peierls, B.L (2008). Ecological responses of the Neuse River-Pamlico Sound estuarine continuum to a period of elevated hurricane activity: Impacts of individual storms and longer term trends. American Fisheries Society Symposium 64: 101-116. 